\title{
Edukasi PHBS di Tatanan Rumah Tangga Untuk Meningkatkan Perilaku Sehat
}

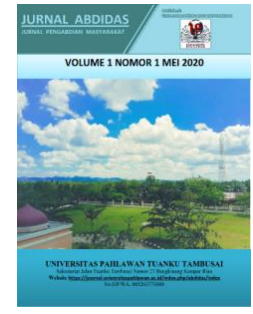

\section{Ade Saputra Nasution}

\author{
Universitas Ibn Khaldun, Bogor, Indonesia ${ }^{1}$ \\ e-mail : adenasution@uika-bogor.ac.id ${ }^{1}$
}

\begin{abstract}
Abstrak
Penerapan perilaku hidup bersih dan sehat di masyarakat masih rendah karena kurangnya sosialisasi terkait manfaat dan risiko bila tidak menerapkan perilaku hidup bersih dan sehat dalam kehidupan sehari-hari. karena rendahnya sosialisai perilaku hidup bersih dan sehat maka kemauan masyarakat dalam penerapan juga rendah yang berakibat kepada kesehatan masyarakat yang terganggu. Pengabdian masyarakat ini bertujuan untuk memberdayakan masyarakat, meningkatkan, melindungi dan memelihara kesehatan sehingga masyarakat sadar, mau dan mampu secara mandiri ikut terlibat aktif dalam penerapan perilaku hidup bersih dan sehat (persalinan ditolong oleh tenaga kesehatan, penimbangan bayi dan balita, membrantas jentik nyamuk, menggunakan air bersih, makan buah dan sayur setiap hari) dikehidupan sehari-hari. Metode pengabdian masyarakat ini menggunakan penyuluhan sebagai peningkatan pengetahuan masyarakat tentang perilaku hidup bersih dan sehat di tatanan rumah tangga dan kegiatan ini dilakukan di RW 5 Kelurahan Rancamaya Bogor. Hasil dari pengabdian masyarakat diperoleh adanya peningkatan pengetahuan setelah diberikan penyuluhan dan adanya perubahan perilaku masyarakat untuk menjalankan perilaku hidup bersih dan sehat dalam kehidupan sehari-hari.
\end{abstract}

Kata Kunci: Perilaku, bersih, sehat

\begin{abstract}
The application of clean and healthy living behaviors in the community is still low due to the lack of socialization related to the benefits and risks of not implementing clean and healthy living behaviors in daily life. Because of the low level of socialization of clean and healthy living, the people's willingness to apply is also low which results in disturbing public health. This community service aims to empower the community, improve, protect and maintain health so that the community is aware, willing and able to be actively involved in the implementation of clean and healthy behavior (childbirth is helped by health workers, weighing infants and toddlers, eradicating mosquito larvae, using clean water, eat fruits and vegetables every day) in daily life. This community service method uses counseling as an increase in community knowledge about clean and healthy living behavior in the household setting. As a result of community service, there is an increase in knowledge after being given counseling and a change in community behavior to carry out clean and healthy life behaviors in daily life.
\end{abstract}

Keywords: behavior, clean, healthy

Copyright (c) 2020 Ade Saputra Nasution

$\triangle$ Corresponding author : Ade Saputra Nasution

Address : Universitas Ibn Khaldun

ISSN 2721-9224 (Media Cetak)

Email : adenasution@uika-bogor.ac.id

ISSN 2721- 9216 (Media Online)

Phone : 081331809846

DOI: https://doi.org/10.31004/abdidas.v1i2.9 


\section{PENDAHULUAN}

Pemerintah Indonesia menjalankan sebuah program untuk menggerakan pola hidup sehat di masyarakat, yang dinamakan perilaku hidup bersih dan sehat (PHBS). PHBS mempunyai lima ruang lingkup yang diantaranya adalah PHBS tatanan rumah tangga, tatanan tempat kerja, tatanan fasilitas kesehatan, tatanan institusi pendidikan dan tatanan tempat umum. PHBS merupakan suatu praktik tentang perilaku masyarakat atau seseorang berlandaskan kesadaran yang merupakan hasil dari proses pembelajaran sehingga menjadikan seseorang, kelompok, keluarga atau masyarakat dapat secara mandiri menolong diri sendiri dalam bidang kesehatan dan derajat kesehatan di masyarakat dapat ditingkatkan. Dasar untuk mewujudkan kesehatan di masyarakat pada tatanan PHBS adalah ruang lingkup di rumah tangga. Hal ini dikarenakan rumah tangga merupakan sumber utama atau pertama terbentuknya perilaku dalam pola hidup bersih dan sehat (Permatasari et al., 2019).

Sasaran primer atau indikator PHBS pada tatanan rumah tangga dianggap dapat mencerminkan dan mewakili keseluruhan perilaku hidup bersih dan sehat yaitu pemberian ASI (air susu ibu) eksklusif, persalinan ditolongan oleh tenaga kesehatan, menimbang balita setiap biulan, penggunaan air bersih, mencuci tangan dengan air bersih dan sabun, jamban sehat, memberantas jentik nyamuk, mengelola sampah dengan membuang pada tempat sampah, mengkonsumsi buah dan sayur setiap hari, melakukan aktivitas fisik setiap hari dan tidak merokok di dalam rumah (Gunawan, Drew, Nindi R, \& Al, 2018; Irawan, 2014).

PHBS di tatanan keluarga masih belum dimengerti oleh masyarakat karena masih kurangnya informasi yang diterima dan masih kurangnya fasilitas untuk melaksanakan program tersebut. Namun ada faktor lain juga seperti masalah ekonomi, keterbelakangan sosial dan pendidikan yang menjadi masalah dalam melaksanakan PHBS. Permasalahan kesehatan di masyarakat seringkali muncul tanpa diketahui dan disadari penyebabnya. Hal ini terjadi karena masih rendahnya tingkat pengetahuan masyarakat mengenai kesehatan. Masalah kesehatan yang terjadi di masyarakat paling sering muncul adalah kematian ibu dan anak yang masih tinggi, penyakit menular, tidak menular, gizi buruk, pola hidup tidak sehat (Auliya, 2014; Hadiyanto, 2016).

Apabila upaya PHBS dapat dilaksanakan secara baik, maka akan menjadi sebuah upaya yang efektif dapat mencegah penyakit dan PHBS dikatakan sebagai determinan penyakit. Maka untuk meningkatkan PHBS di masyarakat perlu sebuah upaya pemberdayaan masyarakat melalui promosi kesehatan seperti penyuluhan atau edukasi kepada masyarakat. Pemberdayaan masyarakat adalah bagian penting dan sebagai ujung tombak untuk melakukan promosi kesehatan. Penyuluhan kesehatan merupakan metode yang dapat diaplikasikan dalam tindakan preventif untuk mengingatkan masyarakat dan menjaga kesehatan individu maupun masyarakat. Melalui metode penyuluhan maka pemeliharaan kesehatan masyarakat dapat dimulai dari kesadaran setiap individu, keluarga, kelompok dan masyarakat luas. Dengan kegiatan pengabdian masyarakat ini dapat mendukung hak literasi informasi kesehatan setiap individu (Patilaiya \& Rahman, 2018).

Promosi kesehatan dapat memberikan pembelajaran pada masyarakat untuk membantu memiliki pengetahuan atau pemahaman, kemampuan dan kemauan mulai dari tingkat individu, keluarga, kelompok atau masyarakat untuk berPHBS. Perilaku masyarakat yang disadari dengan pengetahuan akan lebih langgeng daripada perilaku yang tidak disadari pengetahuan (Sari \& Sulistyowati, 2017).

Kelurahan Rancamaya merupakan wilayah kerja dari Puskesmas Cipaku yang ada di Kota Bogor, berdasarkan analisis awal sebelum 
melakukan pengabdian ditemukan masih banyaknya warga berperilaku tidak sehat salah satunya merokok didalam rumah, buang sampah sembarangan, ASI eksklusif tidak terlaksana dengan baik, kurangnya kunjungan ke Posyandu, melahirkan pada dukun bukan ditolong tenaga kesehatan maupun pembuangan limbah cair domestik yang sangat mengganggu. Dimana kegiatan ini bertujuan untuk meningkatkan pengetahuan, pemahaman dan kesadaran masyarakat tentang PHBS di rumah tangga untuk mencapai derajat kesehatan masyarakat yang setinggi-tingginya.

\section{METODE}

Metode yang digunakan dalam pengabdian ini berupa penyuluhan PHBS dimana sebelumnya dilakukan analisis situasi di RW 5 Kelurahan Rancamaya Kota Bogor, selanjutkan dilakukan pemetaan pengetahuan masyarakat tentang PHBS, penguatan pemahaman PHBS melalui penyuluhan dan evaluasi pengetahuan masyarakat. Mahasiswa yang ikut terlibat dalam penyuluhan PHBS adalah sebanyak 6 orang beserta 1 orang dosen.. persiapan dan pelaksanaan pengabdian dimulai pada tanggal 10 - 12 oktober 2019 yang diikuti oleh 15 orang dan kegiatan dilakukan di Posyandu RW 05.

\section{HASIL DAN PEMBAHASAN}

Kegiatan pengabdian dilaksanakan dengan metode penyuluhan kepada warga RW 05 Kelurahan Rancamaya Kota Bogor. Kegiatan pengabdian PHBS disambut baik oleh masyarakat karena dapat menambah pengetahuan mereka tentang pola hidup sehat dalam kehidupan seharihari.

Tabel 1. Pengetahuan Sebelum dan Sesudah Penyuluhan PHBS

\begin{tabular}{lcccc}
\hline \multirow{1}{*}{\begin{tabular}{c}
\multirow{1}{*}{ Indikator } \\
PHBS
\end{tabular}} & \multicolumn{4}{c}{ Pengetahuan } \\
\cline { 2 - 5 } & Baik & Cukup & Baik & Cukup \\
$\begin{array}{l}\text { Pertolongan } \\
\text { persalinan } \\
\text { oleh nakes }\end{array}$ & 5 & 10 & 15 & 0 \\
\begin{tabular}{l} 
Penimbangan \\
\hline
\end{tabular} & 7 & 8 & 15 & 0 \\
\hline
\end{tabular}

\begin{tabular}{lllll}
\hline $\begin{array}{l}\text { Bayi dan } \\
\text { Balita }\end{array}$ & & & & \\
\hline $\begin{array}{l}\text { Memberantas } \\
\text { jentik } \\
\text { nyamuk }\end{array}$ & 14 & 1 & 15 & 0 \\
$\begin{array}{l}\text { Konsumsi } \\
\text { buah dan } \\
\text { sayur }\end{array}$ & 6 & 9 & 13 & 2 \\
Air bersih & 13 & 2 & 15 & 0 \\
\hline
\end{tabular}

Survei Awal atau analisis situasi awal dilakukan untuk melakukan kajian situasi dibidang kesehatan yang ada di RW 05, hasilnya menunjukan adanya kebutuhan informasi tentang program PHBS ditatanan keluarga. Selanjutnya melakukan penggalian informasi tentang PHBS yang sudah diketahui atau belum oleh peserta. Hasilnya diketahui bahwa banyak peserta merasa belum mendapatkan informasi tentang PHBS dari petugas kesehatan. Ada kemungkinan masyarakat sasaran memang tidak mengikuti kegiatan penyuluhan rutin yang dilakukan oleh petugas kesehatan sebelumnya.

Penguatan pemahaman atau pengetahuan tentang PHBS dilakukan dengan cara penyampaian materi dalam bentuk penyuluhan dan pengamatan implementasi praktik PHBS yang dilakukan peserta. Materi PHBS disampaikan pada peserta dan menjelaskan ruang lingkup dari PHBS yaitu : Bahaya merokok bagi kesehatan, kebiasaan cuci tangan pakai sabun, ibu hamil memeriksakan ke tenaga kesehatan, berolahraga secara teratur, makan buah dan sayur setiap hari, membuang sampah pada tempatnya, memeriksakan Bayi dan Balita Ke Posyandu, memberantas jentik nyamuk, menggunakan air bersih, jamban sehat.

Metode ceramah digunakan dalam promosi kesehatan untuk menyampaikan materi terkait program PHBS. Selanjutnya dilakukan diskusi dan tanya jawab untuk memberikan kesempatan kepada peserta untuk menyampaikan segala sesuatu yang berkaitan dengan PHBS. Pendapat yang dikemukankan oleh peserta diantaranya minimnya informasi yang dapat 
diperoleh dan minimnya petugas kesehatan memberikan penyuluhan kepada warga. Selain itu fasilitas sarana dan prasaran yang menunjang kesehatan di wilayah tersebut belum optimal.

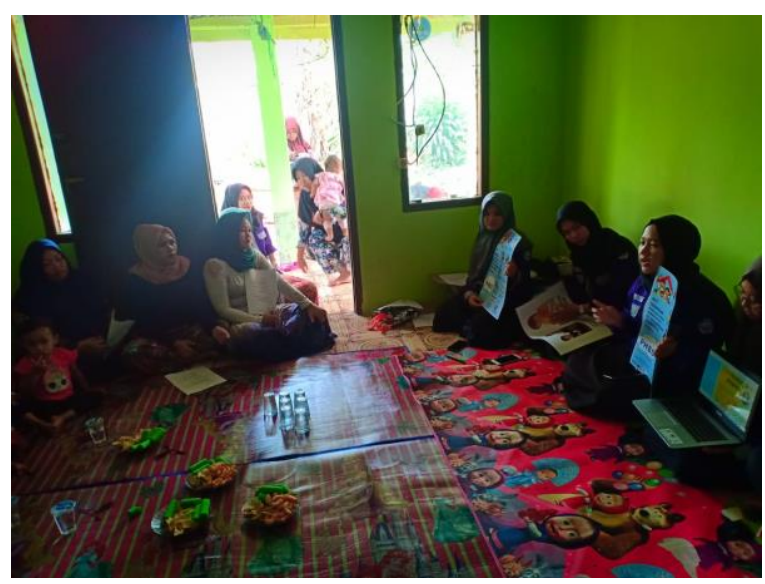

Gambar 1. Penyuluhan PHBS

Selanjutnya dilakukan evaluasi pada tahap akhir rangkaian kegiatan pengabdian dengan kembali mengukur pemahaman tentang PHBS dari peserta sampai sejauhmana promosi kesehatan yang telah dilakukan dapat dipahami oleh peserta. Hasilnya dari evaluasi yang dilakukan menunjukkan adanya peningkatan pengetahuan atau pemahaman tentang PHBS, namun tetap harus dilakukan evaluasi secara intensif terkait implemantasi berdasarkan pemahaman peserta mengenai PHBS.

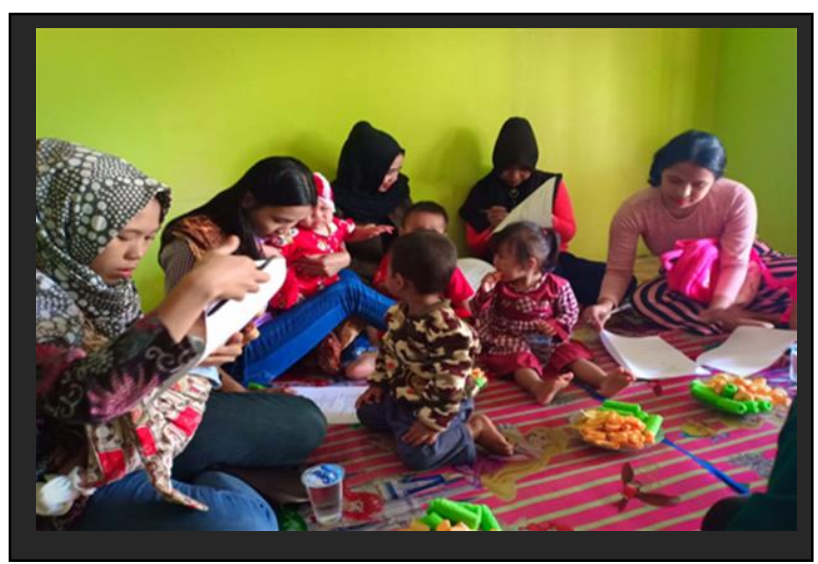

Gambar 2. Pengisian Kuesioner Pengetahuan PHBS

\section{SIMPULAN}

Melalui evaluasi pos tes pengetahuan peserta tentang PHBS mengalami kenaikan dan peningkatan pernyataan sikap untuk melaksanakan PHBS dalam kehidupan sehari-hari.

\section{UCAPAN TERIMA KASIH}

Penulis mengucapkan terimaksih kepada Universitas Ibn Khaldun Bogor Program Studi Kesehatan Masyarakat yang telah memberikan kesempatan untuk melaksanakan salah satu tri dharma perguruan tinggi yaitu pengabdian kepada masyarakat, penulis juga mengucapkan terimaksih kepada masyarakat yang telah mau menerima penulis untuk melakukan edukasi PHBS dan kepada mahasiswa yang telah membantu dari awal sampai terselenggaranya kegiatan pengabdian ini.

\section{DAFTAR PUSTAKA}

Auliya, R. (2014). Hubungan Antara PHBS Tatanan Rumah Tangga dan Sanitasi Rumah Dengan Kejadian Leptospirosis. Unnes Journal of Public Health., 3(3), 1-10. https://doi.org/10.15294/ujph.v3i3.3543

Gunawan, S., Drew, C., Nindi R, D. C., \& Al, E. (2018). Penyuluhan "perilaku Hidup Bersih Sehat (PHBS)" Dalam Rangka Program Tentara Manunggal Masuk Ddesa (TMMD) Wilayah Kodim 0510 Tigaraksa, Tangerang. 1(2), 133-142.

Hadiyanto, H. (2016). Perilaku Hidup Bersih dan Sehat (PHBS) Tatanan Keluarga di Posdaya Al-Fadillah. Jurnal Surya Pengabdian Kepada Masyarakat, 2(1), 89-100. Retrieved from

https://jurnal.ummi.ac.id/index.php/JSU/artic le/view/54

Irawan, A. Y. (2014). Hubungan Antara Aspek Kesehatan Lingkungan Dalam PHBS Rumah Tangga Dengan Kejadian Penyakit Diare Di Kecamatan Karangreja Tahun 2012. Unnes Journal of Public Health, 2(4).

Patilaiya, H. La, \& Rahman, H. (2018). Pemberdayaan Masyarakat Melalui Penyuluhan Perilaku Hidup Bersih dan Sehat untuk Meningkatkan Kualitas Kesehatan Masyarakat. JPPM (Jurnal Pengabdian Dan Pemberdayaan Masyarakat), 2(2), 251. https://doi.org/10.30595/jppm.v2i2.2512

Permatasari, J., Gusnawangti, G., Safitri, D. F., Luthfia, F., Orlanda, D., Ariani, M., ... Fitriah, F. (2019). Penyuluhan PHBS Dalam 
Mewujudkan Masyarakat Dusun Talang Parit Peduli Akan Kesehatan. Jurnal Pengabdian Harapan Ibu (JPHI), I(1), 18-23. https://doi.org/10.30644/jphi.v1i1.194

Sari, I. I. K., \& Sulistyowati, M. (2017). Analisis Promosi Kesehatan Di Puskesmas Kalijudan Terhadap PHBS Rumah Tangga Ibu Hamil. Jurnal PROMKES, 3(2), 159. https://doi.org/10.20473/jpk.v3.i2.2015.159170 